\title{
NILAI PEMBUKTIAN SERTIFIKAT HAK ATAS TANAH
}

\author{
Sitti Maryam Patajai \\ Mahasiswa Program Pascasarjana Universitas Muslim Indonesia Makassar \\ email : maryam.patajai@gmail.com
}

\begin{abstract}
Every plot of land controlled and/or owned wherever possible is secured from the possibility of a dispute with another person, by being registered with the competent authority to obtain protection and guarantee of legal certainty. Land rights certificates have perfect verification value, therefore they can serve as powerful evidence.

The certificate of title to land as an authentic deed has the power of proof of birth of formal proof, because all the explanations contained therein are viewed as information from the issuing official and its issuance in accordance with the applicable law provisions so it is very difficult to be canceled or declared invalid.
\end{abstract}

Keywords: Land Rights; Certificate; Evidence;

Setiap sebidang tanah yang dikendalikan dan / atau dimiliki sedapat mungkin dijamin dari kemungkinan perselisihan dengan orang lain, dengan didaftarkan pada otoritas yang kompeten untuk mendapatkan perlindungan dan jaminan kepastian hukum. Sertifikat hak tanah memiliki nilai verifikasi sempurna, oleh karena itu mereka dapat berfungsi sebagai bukti kuat.

Sertifikat hak milik atas tanah sebagai akta otentik memiliki kekuatan bukti kelahiran bukti formal, karena semua penjelasan yang terkandung di dalamnya dipandang sebagai informasi dari pejabat penerbit dan penerbitannya sesuai dengan ketentuan hukum yang berlaku sehingga sangat sulit dibatalkan atau dinyatakan tidak valid.

Kata kunci: Sertifikat; Hak Tanah; Alat Bukti;

\section{A. PENGANTAR}

Dewasa ini masalah tanah telah terjadi dimana-mana dan biasanya diberitakan berbagai media massa, baik cetak maupun elektronik. Terhadap permasalahan tanah, maka bagi mereka yang tergolong sebagai maha terpelajar dan orang terpelajar, tentu dapat dengan mudah menarik suatu konklusi bahwa tanah yang ada dalam penguasaan (dimiliki) seseorang perlu diamankan dari segala kemungkinan terjelek yang akan menimpanya. Atau dengan kata lain, bahwa setiap bidang tanah selalu berpotensi terjadi persengketaan. Kalau hal ini benar-benar terjadi, maka menurut optik hukum, hendaknya diselesaikan melalui keterlibatan lembaga pemutus yang independen. Paling tidak, sangat diharapkan agar pengadilan sebagai ultimatum remedium dapat mengaplikasikan perannya sesuai dengan prinsip quick and lower in time and money to the parties. Sehingga untuk maksud tersebut, maka seyogyanya perlu ada langkah-langkah pengamanan yang bertujuan untuk mengantisipasi terjadinya sengketa tanah. 
Pentingnya mengamankan setiap bidang tanah yang ada dalam penguasaan dan/atau pemilikan seseorang, dengan maksud agar dapat terhindar dari suatu persengketaan tanah. Secara empirik dalam masyarakat bahwa apabila sebidang tanah yang ada dalam penguasaan (dimiliki) seseorang menjadi obyek sengketa. maka secara ex officio penyelesaian persengketaan tanah akan menguras tenaga, pikiran, waktu, kesempatan, dan biaya. Bagi mereka yang menguasai ataupun memiliki sebidang tanah perlu melakukan pengamanan. Setidak-tidaknya yang bersangkutan, sejak dari dini sudah harus mempersiapkan diri mengamankan bidang tanah yang ada dalam penguasaan atau miliknya dari serangan pihak luar. Pentingnyamempersiapkan diri dari kemungkinan terjadinya persengketaan tanah, karena masalah dan/atau sengketa tanah tidak dapat diprediksi kapan terjadinya. Salah satu cara untuk mempersiapkan diri dari kemungkinan terjadinya persengketaan tanah, yakni setiap bidang tanah yang ada dalam penguasaan atau dimiliki hendaknya didaftarkan pada instansi yang berwenang guna mendapatkan dokumen (akta otentik) dalam bentuk sertifikat tanah (Sertifikat Hak Milik Atas Tanah disingkat SHM).

\section{B. ANALISIS DAN PEMBAHASAN}

\section{Eksistensi Tanah Menurut Undang Undang Dasar Negara Republik Indonesia Tahun 1945}

Dari segi dogmatik-normatif terhadap eksistensi tanah menurut konsepsi Pasal 33 ayat (3) UUD NRI Tahun 1945, berbunyi; "Bumi dan air dan kekayaan alam yang terkandung di dalamnya dikuasai oleh negara dan dipergunakan untuk sebesar-besar kemakmuran rakyat". Jika demikian, maka eksistensi tanah dalam konstitusi negara dipandang sebagai bagian integral dari bumi dan sekaligus dianggap sebagai fasilitas atau sarana yang dapat diberdayakan oleh pemerintah dalam rangka peningkatan kesejahteraan dan kemakmuran seluruh rakyat Indonesia. Karena itu, tidak mengherankan apabila Pemerintah berupaya untuk menjabarkan amanah Pasal 33 ayat (3) UUD NRI Tahun 1945 ke dalam suatu undang-undang (regulasi). Sedang tujuan Pemerintah membentuk dan menyusun suatu regulasi, agar nantinya dapat dipergunakan sebagai hukum tanah (hukum pertanahan) yang bersifat nasional dan merupakan bagian integral dari hukum agaria (pengertian sempit) dan dituangkan ke dalam Undang-undang Nomor 5 Tahun 1960 tentang Peraturan Dasar Pokok-pokok Agraria atau lebih dikenal dengan Undang-undang Pokok Agraria (UUPA). Pengaturan tanah dalam UUPA, hanya terfokus pada kulit bumi (tubuh bumi, fisik tanah). Artinya tidak termasuk masalah keagrariaan lainnya, seperti; air, ruang angkasa dan kekayaan alam yang terkandung di dalamnya, sebagaimana dimaksud dalam konstitusi negara. Setidak-tidaknya Hukum Tanah Nasional, mengatur hakhak atas tanah dan hak-hak yang berhubungan dengan tanah.

Dalam kaitan ini, eksistensi tanah menurut S. Rowton Simpson mengkategorikan tanah sebagai benda tidak bergerak dan secara faktual memang benar fisik tanah tidak dapat diserahkan/dipindah/dibawa, bahkan setiap bidang tanah selalu bersifat abadi. Kemudian pada versi yang lain, dapat dikatakan bahwa tanah (land) tiada lain daripada permukaan bumi termasuk benda yang bernilai ekonomis, dan sekaligus sebagai magis- religio- 
kosmis. Namun apabila ditelaah UUPA menganut asas horizontal, maka dimungkinkan adanya hak di atas hak. Artinya; hak yang melekat di atas tanah terpisah dengan hak yang melekat pada benda (rumah, bangunan, tanaman) yang ada di atas tanah yang bersangkutan (hak atas tanah dengan hak-hak yang ada hubungannya dengan tanah).

Pada dasarnya UUPA mengatur adanya hak atas tanah yang bersifat permanen dan yang bersifat sementara. Hak-hak atas tanah yang bersifat permanen diatur dalam Pasal 16 ayat (1) UUPA, yakni; "hak milik, hak guna usaha, hak guna bangunan, hak pakai, hak sewa, hak membuka tanah, hak memungut hasil hutan, dan hak-hak lain yang tidak termasuk dalam hak-hak tersebut di atas yang akan ditetapkan dengan Undang-undang serta hak-hak yang sifatnya sementara sebagai yang disebutkan dalam Pasal 53 UUPA".

Kemudian hak-hak atas tanah yang bersifat sementara menurut Pasal 16 ayat (1) UUPA dan Pasal 53 UUPA, yakni; "Hak-hak yang sifatnya sementara sebagai yang dimaksud dalam Pasal 16 ayat (1) huruf $h$, ialah hak gadai, hak usaha bagi hasil, hak menumpang dan hak sewa tanah pertanian diatur untuk membatasi sifat-sifatnya yang bertentangan dengan Undangundang ini dan hak-hak tersebut diusahakan hapusnya di dalam waktu yang singkat".

Namun demikian, ternyata UUPA juga membuka kesempatan kepada setiap warga negara Indonesia untuk dapat menguasai dan/atau memiliki bidang-bidang tanah tertentu di Indonesia. Dalam praktik; banyak cara yang dapat dilakukan untuk memperoleh sebidang tanah, misalnya perolehan tanah secara legal (sesuai hukum) antara lain dengan cara; melalui transaksi jual beli, tukar-menukar, pewarisan ataupun penghibaan. Kendatipun tidak jarang terjadi adanya perolehan tanah secara illegal (melawan hukum), seperti; penyerobotan, penipuan, pemalsuan surat-surat tanah, ataupun pengambilan secara paksa. Karena itu, tidaklah mengherankan apabila keadaan (situasi dan kondisi) yang ada di sekitar lingkungan masing-masing, dimana setiap bidang tanah sering dijadikan sebagai obyek persengketaan. Persoalannya sekarang, upaya apa saja yang seyogyanya dilakukan untuk mengamankan bidang-bidang tanah yang dimiliki atau dikuasai guna mendapatkan jaminan perlindungan dan kepastian hukum dari Pemerintah? Sedang menurut teori hukum, terutama bagi mereka yang menganut aliran juridis formal, bahwa kepastian hukum merupakan salah satu tujuan hukum. Atau dengan pertanyaan lain, apakah sertifikat tanah sebagai produk lembaga pendaftaran tanah dapat dijadikan solusi dalam berusaha mengantisipasi agar setiap bidang tanah yang dimiliki ataupun dikuasai tidak menjadi objek persengketaan?

\section{Pendaftaran Tanah}

Wilayah Negara Indonesia yang terbentang dari Sabang sampai ke Merauke, terdiri dari berjuta-juta bidang tanah. Karena itu, maka kehadiran Negara (Pemerintah) untuk melakukan pengaturan terhadap setiap bidang tanah sangat urgen. Secara normatif, Negara memang diberi wewenang untuk melakukan pengaturan terhadap setiap bidang tanah. Kewenangan pengaturan terhadap setiap bidang tanah dimaksud, tersurat dalam Pasal 2, Pasal 4 dan Pasal 19 ayat (1) UUPA. 
Di dalam Pasal 19 ayat (1) UUPA ditentukan bahwa; "Untuk menjamin kepastian hukum oleh Pemerintah diadakan pendaftaran tanah di seluruh wilayah Republik Indonesia menurut ketentuan-ketentuan yang diatur dengan Peraturan Pemerintah". Adapun tata cara dan prosedur pelaksanaan pendaftaran tanah, dilakukan dengan cara sederhana dan mudah dimengerti serta dijalankan oleh seluruh rakyat yang menguasai dan/atau memiliki bidang-bidang tanah tertentu. Sehubungan dengan hal tersebut, sehingga Pemerintah dalam menyelenggarakan tugas dan pekerjaan yang berorientasi kepada pelaksanaan pendaftaran tanah yang dapat diklasifikasi atas tiga jenis, sebagai berikut :

1. Pendaftaran hak-hak atas tanah yang berkaitan dengan masalah kehutanan atau pertambangan, dilakukan oleh departemen/instansi yang bersangkutan.

2. Pendaftaran tanah untuk kepentingan penggunaan dan pemanfaatan tanah dalam kaitannya dengan perpajakan atau cadastre (lembaga girik, petuk, letter $\mathrm{C}$ maupun PBB), dilakukan oleh departemen keuangan.

3. Pendaftaran hak atas tanah untuk kepentingan kepastian hukum tentang penguasaan dan pemilikan tanah, dilakukan oleh Menteri Negara Agraria/Kepala Badan Pertanahan Nasional (MNA/KBPN).

Di antara ketiga jenis pendaftaran tanah di atas, maka penyelenggaraan pendaftaran tanah jenis yang ketiga ini disebut pendaftaran tanah (pendaftaran hak atas tanah). Sedang untuk penyelenggaraannya, menjadi tugas dan tanggung jawab Pemerintah selaku pelaksana negara yang dalam hal ini dibebankan kepada MNA/KBPN beserta jajarannya. Kemudian untuk aplikasi lebih lanjut, secara garis besar tugas dan tanggung jawab MNA/KBPN dalam rangka penyelenggaraan pendaftaran tanah diatur dalam PP. No. 24 Tahun 1997 tentang Pendaftaran Tanah.

Ratio logis dari makna pendaftaran tanah menurut PP. Nomor 24 Tahun 1997, adalah; "rangkaian kegiatan yang dilakukan oleh Pemerintah secara terus-menerus, berkesinambungan dan teratur meliputi pengumpulan, pengolahan, pembukuan dan penyajian serta pemeliharaan data fisik dan data juridis, dalam bentuk peta dan daftar, mengenai bidang-bidang tanah dan satuan-satuan rumah susun, termasuk pemberian surat tanda bukti haknya bagi bidang-bidang tanah yang sudah ada haknya dan hak milik atas satuansatuan rumah susun serta hak-hak tertentu yang membebaninya".

Selanjutnya yang menjadi objek penyelenggaraan pendaftaran tanah, telah diatur secara limitatif dalam Pasal 9 PP. No. 24 Tahun 1997, terdiri dari:

a. Bidang-bidang tanah yang dipunyai dengan hak milik, hak guna usaha, hak guna bangunan dan hak pakai;

b. Tanah hak pengelolaan;

c. Tanah wakaf;

d. Hak milik atas satuan rumah susun;

e. Hak tanggungan; dan

f. Tanah negara.

Berkenaan dengan telah dilakukannya pendaftaran tanah, maka secara ex officio bidang-bidang tanah yang sudah didaftarkan pada instansi yang berwenang dan sesuai ketentuan hukum yang berlaku berkesempatan untuk 
mendapatkan jaminan perlindungan dan kepastian hukum dari Negara dalam bentuk pemberian sertifikat hak atas tanah. Namun demikian, keberadaan sertifikat hak atas tanah sebagai salah satu bentuk jaminan pemberian kepastian hukum dari Pemerintah kepada pemilik atau orang yang menguasai bidang-bidang tanah tertentu, bukanlah kepastian mutlak, karena sistem hukum yang berlaku positif di Indonesia, masih memungkinkan dilakukan pembuktian sebaliknya.

\section{Sistem, Asas dan Tujuan Pendaftaran Tanah}

\section{a. Sistem Pendaftaran Tanah}

Menurut ajaran teori sistem dengan tegas mengungkapkan, bahwa ... a system can be defined as an organized group of components (subsystem) linked together according to a plan to a chieve a specific objective. Sehingga sistem dapat dikatakan sebagai kesatuan (unity) yang terdiri dari bagian-bagian (parts), component, element, secondary system (subssystem), yang secara fungsional terkait satu sama lain dalam ikatan super ordinatnya yang menunjukkan suatu gerak dalam rangka mencapai goal attainment atau suatu tujuan tertentu. Sedang mengenai pendaftaran tanah sebagai suatu sistem, maka teknis penyelenggaraannya masih harus disesuaikan dengan sistem hukum yang berlaku pada negara yang bersangkutan.

Pendaftaran tanah yang dilakukan di Indonesia, menganut sistem publikasi. Di dalam teori hukum pendaftaran tanah, sistem publikasi dibedakan antara sistem publikasi positif (kebenaran data yang disajikan dalam sertifikat tanah dijamin oleh negara), dan sistem publikasi negatif (negara tidak menjamin kebenaran data yang disajikan dalam sertifikat tanah). Menurut Pasal 19 ayat (2) huruf c UUPA, ditegaskan bahwa surat tanda bukti hak yang diterbitkan berlaku sebagai alat bukti yang kuat. Hal ini bersinergi dengan Pasal 23, Pasal 32 dan Pasal 38 UUPA, bahwa pendaftaran sebagai peristiwa hukum merupakan alat pembuktian yang kuat. Dengan demikian Indonesia tidak secara tegas menganut sistem publikasi negatif dalam penyelenggaraan pendaftaran tanah. Walaupun diakui bahwa setiap negara dalam menyelenggarakan pendaftaran tanah, senangtiasa mempunyai ciri khas tersendiri. Karena itu, wajar dan patut apabila tidak ada negara yang persis sama pelaksanaan pendaftaran tanahnya. Sekalipun sistem yang dipakai sama, tetapi karena masingmasing negara mempunyai ciri-ciri khusus, sehingga berbeda dengan pendaftaran tanah pada negara yang lain.

Pada prinsipnya, kepastian hukum yang dijanjikan dalam rangka pelaksanaan pendaftaran tanah sangat tergantung daripada sistem pendaftaran tanah yang dianut oleh negara yang bersangkutan. Secara teoretis, bahwa dalam hukum pertanahan dikenal ada tiga jenis sistem pendaftaran tanah, yakni :

a. Sistem Torrens; ciri utamanya sertifikat tanah merupakan alat bukti pemegang hak atas tanah yang paling lengkap dan tidak bisa diganggugugat. Untuk merubah buku tanah adalah tidak mungkin, terkecuali jika memperoleh sertifikat tanah dengan cara pemalsuan ataupun penipuan. 
Sistem ini dipakai di Australia, Kepulauan Fiji, Canada, Negara Bagian Lowa Amerika Serikat, Yamaika Trinidad, Brazilia, Aljazair dan beberapa negara lainnya.

b. Sistem Positif; ciri pokoknya menjamin dengan sempurna nama yang terdaftar dalam buku tanah. Data tentang subyek hukum yang tercatat dalam buku tanah, tidak dapat dibantah sekalipun ternyata bukanlah pemilik yang berhak atas tanah yang bersangkutan. Sistem ini dipakai di Jerman dan Swis.

c. Sistem Negatif; ciri pokoknya tidak menjamin nama-nama yang terdaftar dalam buku tanah, dapat untuk dibantah jika nama yang terdaftar bukanlah pemilik yang sebenarnya. Dalam sistem yang demikian ini, maka Pejabat Balik Nama Tanah berperan pasif, artinya pejabat yang bersangkutan tidak berkewajiban untuk menyelidiki kebenaran dari surat-surat yang diserahkan kepadanya. Sistem ini dipakai di Prancis dan Nederland.

Berkenaan dari ketiga sistem pendaftaran tanah tersebut, wajar dan patut apabila dipertanyakan; sistem pendaftaran tanah apakah yang dipakai di Indonesia? Jawabannya; Indonesia menggunakan sistem positif yang menganut unsur-unsur negatif, (bertendensi negatif) sebagaimana tersimpul dari Pasal 19 UU. No. 5 Tahun 1960 juncto Pasal 19 ayat (2) huruf c, 23 ayat (2), 32 ayat (2) dan Pasal 38 ayat (2) PP. No. 24 Tahun 1997.

\section{b. Asas Hukum Pendaftaran Tanah}

Eksistensi asas hukum merupakan jantungnya peraturan hukum sekaligus sebagai sesuatu yang melahirkan peraturan/aturan hukum, sehingga merupakan ratio logis dari aturan ataupun peraturan hukum, karena mengandung nilai-nilai dan tuntutan-tuntutan etis atau adanya petunjuk ke arah itu. Adapun asas hukum penyelenggaraan pendaftaran tanah di Indonesia, diatur secara limitatif dalam Pasal 2 PP. Nomor 24 Tahun 1997, bahwa; "Pendaftaran tanah dilaksanakan berdasarkan asas sederhana, aman, terjangkau, mutakhir dan terbuka".

Kelima asas hukum ini, yang harus menjadi jiwa dan semangat terhadap penyelenggaraan pendaftaran tanah di Indonesia, agar out put yang dicapai benar-benar dapat memberikan jaminan perlindungan dan kepastian hukum. Dalam Penjelasan Pasal 2 PP No. 24 Tahun 1997, diungkapkan arti dan makna dari setiap asas hukum pendaftaran tanah dimaksud, sebagai berikut:

a. Asas sederhana; dalam pendaftaran tanah dimaksudkan agar ketentuan-ketentuan pokoknya maupun prosedurnya dengan mudah dapat dipahami oleh pihak-pihak yang berkepentingan, terutama para pemegang hak atas tanah.

b. Asas aman; dimaksudkan untuk menunjukkan, bahwa pendaftaran tanah perlu diselenggarakan secara teliti dan cermat sehingga hasilnya dapat memberikan jaminan kepastian hukum sesuai tujuan pendaftaran tanah itu sendiri.

c. Asas terjangkau; dimaksudkan keterjangkauan bagi pihak-pihak yang 
memerlukan, khususnya dengan memperhatikan kebutuhan dan kemampuan golongan ekonomi lemah.

d. Asas mutakhir; dimaksudkan kelengkapan yang memadai dalam pelaksanaannya dan keseimbangan dalam pemeliharaan datanya.

e. Asas terbuka; dimaksudkan bahwa data yang disimpan pada Kantor Pertanahan selalu sesuai dengan keadaan nyata di lapangan, dan masyarakat dapat memperoleh keterangan mengenai data yang benar setiap saat.

\section{c. Tujuan Pendaftaran Tanah}

Tujuan hukum diselenggarakannya pendaftaran tanah secara limitatif diatur dalam Pasal 3 PP No. 24 Tahun 1997, yakni :

1. Untuk memberikan kepastian hukum dan perlindungan hukum kepada pemegang hak atas tanah dan hak-hak lain yang terdaftar, agar dengan mudah dapat membuktikan dirinya sebagai pemegang hak yang bersangkutan.

2. Untuk menyediakan informasi kepada pihak-pihak yang berkepentingan termasuk Pemerintah agar dengan mudah dapat memperoleh data yang diperlukan dalam mengadakan perbuatan hukum mengenai bidangbidang tanah yang sudah terdaftar.

3. Untuk menyelenggarakan tertib administrasi pertanahan.

Tujuan utama yang hendak diwujudkan dalam rangka penyelenggaraan pendaftaran tanah adalah untuk memberikan perlindungan dan kepastian hukum bagi para pemilik tanah dalam bentuk pemberian sertifikat hak atas tanah sebagai alat bukti tulisan (otentik). Sedang mengenai kepastian hukum yang hendak diwujudkan dalam pelaksanaan pendaftaran tanah, merupakan bagian integral dari tujuan hukum pada umumnya.

\section{Akibat Hukum Pelaksanaan Pendaftaran Tanah}

Penyelenggaraan pendaftaran tanah, telah diatur dalam PP. No. 24 Tahun 1997, yakni melalui dua cara pendaftaran tanah, sebagai berikut:

1. Pendaftaran tanah secara sistematik (desa demi desa), adalah kegiatan pendaftaran tanah untuk pertama kali yang dilakukan secara serentak yang meliputi semua obyek pendaftaran tanah yang belum didaftar dalam wilayah atau bagian wilayah suatu desa/kelurahan (Pasal 1 angka 10 PP No. 24 Tahun 1997).

2. Pendaftaran tanah secara sporadik (individual), adalah kegiatan pendaftaran tanah untuk pertama kali mengenai satu atau beberapa obyek pendaftaran tanah dalam wilayah atau bagian wilayah suatu desa/kelurahan secara individual atau massal (Pasal 1 angka 11 PP No. 24 Tahun 1997).

Menurut Pasal 11 PP No. 24 Tahun 1997, "Pelaksanaan pendaftaran tanah meliputi kegiatan pendaftaran tanah untuk pertama kali dan pemeliharaan data pendaftaran tanah". Dengan demikian pelaksanaan 
pendaftaran tanah di Indonesia berorientasi pada pendaftaran tanah untuk pertama kali (recording of title) dan pemeliharaan data pendaftaran tanah (continuous recording). Hal yang demikian, sesuai yang dikehendaki Pasal 19 UU No. 5 Tahun 1960.

Adapun jenis-jenis kegiatan yang dilakukan berkenaan dengan pelaksanaan pendaftaran tanah untuk pertama kali, meliputi :

1. Pengumpulan dan pengolahan data fisik;

2. Pembuktian hak dan pembukuannya;

3. Penerbitan sertifikat;

4. Penyajian data fisik dan data yuridis;

5. Penyimpanan daftar umum dan dokumen (Pasal 12 ayat (1) PP No. 24 Tahun 1997).

Lain halnya dengan aktivitas yang harus dilakukan berkenaan dengan pemeliharaan data dalam rangka pelaksanaan pendaftaran tanah, yakni harus dilakukan dua jenis kegiatan, sebagai berikut :

1. Pendaftaran peralihan dan pembebanan hak;

2. Pendaftaran perubahan data pendaftaran tanah lainnya (Pasal 12 ayat (2) PP. Nomor 24 Tahun 1997).

Setiap kegiatan tentu mempunyai akibat hukum, termasuk dengan pelaksanaan pendaftaran tanah, tentu mempunyai akibat hukum baik terhadap bidang tanah yang telah didaftarkan maupun terhadap subyek hukum yang namanya terdaftar sebagai pemegang hak atas tanah. Setidaktidaknya akibat hukum dari pelaksanaan pendaftaran tanah, yakni diterbitkannya sertifikat tanah oleh instansi yang berwenang, lalu diserahkan kepada orang yang namanya tercatat dalam sertifikat tanah sebagai alat untuk mengelak dari adagium yang berbunyi "nemo dat quod non habet".

Berdasarkan hal tersebut, maka pelaksanaan pendaftaran tanah menimbulkan akibat hukum, antara lain :

1. Adanya bidang-bidang tanah tertentu yang perlu mendapatkan perlindungan dan jaminan kepastian hukum dari Negara, yakni khusus terhadap bidang-bidang tanah yang sudah didaftarkan.

2. Negara berkewajiban memberikan perlindungan dan jaminan kepastian hukum terhadap hak-hak atas tanah dan hak-hak privat yang lahir daripadanya karena suatu hubungan hukum, sepanjang hak-hak atas tanah dan hubungan hukum atas tanah itu telah didaftarkan.

3. Tersedianya data fisik dan data juridis atas bidang-bidang tanah yang telah didaftarkan, atau setidak-tidaknya tercipta sistem administrasi pertanahan yang valid dan kredibel.

\section{Alat Bukti Sertifikat Hak Atas Tanah}

\section{a. Sertifikat Hak Atas Tanah}

Di dalam UUPA tidak dikenal istilah sertifikat, melainkan menggunakan istilah alat bukti yang kuat. Akan tetapi di dalam Pasal 31 
ayat (1) PP No. 24 Tahun 1997, antara lain ditegaskan; bahwa "Sertifikat diterbitkan untuk kepentingan pemegang hak yang bersangkutan sesuai dengan data fisik dan data yuridis yang telah didaftar dalam buku tanah". Oleh karena itu, maka ratio logis dari penerbitan suatu sertifikat hak atas tanah semata-mata untuk kepentingan pemegang hak atas tanah yang bersangkutan. Sedang konsekuensi yuridisnya, bahwa pejabat yang berwenang hanya dimungkinkan menyerahkan sertifikat itu kepada seseorang yang namanya tercatat dalam buku tanah, atau kepada seorang lain yang memang diberi kuasa oleh yang bersangkutan.

Istilah sertifikat hak atas tanah atau sertifikat, secara etimologis berasal dari bahasa Belanda yakni "certificaf", artinya surat bukti atau surat keterangan yang membuktikan tentang sesuatu. Mhd. Yamin Lubis dengan tegas menyatakan, bahwa; Sertifikat Tanah adalah surat keterangan yang membuktikan hak seseorang atas sebidang tanah, atau dengan kata lain keadaan tersebut menyatakan bahwa ada seseorang yang memiliki bidangbidang tanah tertentu dan pemilikan itu mempunyai bukti yang kuat berupa surat yang dibuat oleh instansi yang berwenang.

Berkenaan dengan hal tersebut, maka penerbitan sertifikat hak atas tanah, agar supaya pemegang hak atas tanah dapat dengan mudah membuktikan haknya terhadap setiap bidang-bidang tanah tertentu. Pejabat yang berwenang baru akan menerbitkan sertifikat hak atas tanah, apabila terhadap bidang tanah yang bersangkutan sudah bersih dan tidak ada lagi masalah atau catatan-catatan dalam pembukuannya. Sepanjang masih ada catatan-catatan dalam pembukuannya, maka sertifikat hak atas tanah yang bersangkutan tidak atau belum dapat diterbitkan oleh pejabat yang berwenang. Akan tetapi sekiranya catatan-catatan itu hanya mengenai data fisik yang tidak dipersengketakan, maka secara yuridis formal sertifikat hak atas tanah dapat diterbitkan.

Mengenai perseketaan dalam kaitannya dengan penerbitan sertifikat hak atas tanah, hendaknya tidak diidentikkan dengan istilah perkara. Penggunaan istilah perkara (perkara perdata) di dalamnya terkandung dua persoalan pokok, yakni persoalan yang mengandung sengketa (penyelesaiannya melalui gugatan dan out put-nya berupa keputusan) serta persoalan yang tidak mengandung sengketa (penyelesaiannya melalui permohonan dan out put-nya berupa ketetapan). Atau setidak- tidaknya di dalam istilah perkara tersimpul dua keadaan yang berlainan, yaitu ada perselisihan dan tidak ada perselisihan.

Keberadaan sertifikat hak atas tanah mengantisipasi kemungkinan terjadinya persengketaan terhadap bidang tanah yang tercantum dalam sertifikat yang bersangkutan, terkait dengan asas hukum yang berbunyi; "affirmanti inclumbit probate". Asas hukum dimaksud, terumus dalam Pasal 183 RBg dan Pasal 1865 KUH Perdata, kaidah hukumnya berbunyi; "Siapa mengaku mempunyai hak harus membuktikannya". Hal ini bersinergi dengan Yurisprudensi Mahkamah Agung Republik Indonesia (MARI) Nomor 985 K/Sip/1971 - tanggal 12 April 1972, kaidah hukumnya berbunyi; "Pihak yang mendalilkan sesuatu harus dapat membuktikan dalilnya untuk menggugurkan dalil pihak lawan". Bagi pemilik sertifikat, tentu dengan mudah membuktikan haknya di atas bidang tanah yang bersangkutan (Pasal 32 ayat (1) PP No. 24 Tahun 1997). 
Persengketaan tidak dapat diselesaikan oleh pihak-pihak yang bersangkutan sendiri, terlebih lagi kalau menyelesaikannya dilakukan dengan cara main hakim sendiri (eigenrichting). Untuk itu, maka seyogyanyalah apabila penggunaan pranata eigenrichting sebagai salah satu instrumen pengamanan atas tanah yang dikuasai atau dimiliki adalah tidak benar dan sedapat mungkin dihindari. Apabila ada dugaan yang kuat berkenaan dengan telah terjadinya sesuatu perbuatan atau tindakan melanggar hukum terhadap sebidang atau beberapa bidang tanah orang lain, maka terhadap orang yang diduga telah melakukan perbuatan atau tindakan melanggar hukum tidak boleh diambil tindakan langsung dari pihak yang merasa dirugikan dengan cara menghakimi sendiri.

Di samping itu, perbuatan menjadi hakim sendiri (eigenrichting) bertentangan dengan Pasal 702 ayat (1) Rechtsreglement Buitengewesten $(\mathrm{RBg})$ yang di dalamnya terkandung asas hukum nemo judex idoneus in propria causa (tidak seorangpun dapat menjadi hakim yang baik dalam perkaranya sendiri). Menurut hukum; siapa saja yang terbukti secara sah dan meyakinkan bersalah melakukan perbuatan melawan hukum (eigenrichting) harus dihukum. Apabila ada seseorang yang merasa haknya dilanggar oleh orang lain dapat memberdayakan saluran hukum yang telah disediakan di dalam hukum acara (perdata). Karena itu, setiap persengketaan hendaknya diselesaikan melalui prosedur hukum yang berlaku dan melalui pemberdayaan peradilan sebagai lembaga independen dan tidak memihak. Contohnya; sengketa tentang kepemilikan dan/atau penguasaan tanah, penggugat beranggapan bahwa tanah obyek sengketa adalah miliknya, dan tergugat berpendirian tanah sengketa adalah kepunyaannya. Jika demikian, siapa pemilik tanah yang sebenarnya? Persengketaan seperti ini, harus diselesaikan melalui prosedur gugat-menggugat di pengadilan dengan cara mengajukan sertifikat hak atas tanah sebagai bukti tulisan.

\section{b. Sertifikat Hak Atas Tanah Sebagai Alat Bukti}

Pada hakikatnya eksisten sertifikat hak atas tanah sebagai produk pejabat selaku penyelenggaraan pendaftaran tanah, diatur dalam Pasal 32 ayat (1) PP No. 24 Tahun 1997, bahwa; "Sertifikat merupakan surat tanda bukti hak yang berlaku sebagai alat pembuktian yang kuat mengenai data fisik dan data yuridis yang termuat di dalamnya, sepanjang data fisik dan data yuriidis tersebut sesuai data yang ada dalam surat ukur dan buku tanah yang bersangkutan".

Sertifikat yang diterbitkan oleh pejabat yang berwenang merupakan tanda bukti hak yang kuat, dalam arti bahwa selama tidak dibuktikan sebaliknya (asas publikasi negatif). Untuk itu, data fisik dan data yuridis yang tercantum di dalamnya hendaknya diterima sebagai keterangan atau informasi yang benar adanya, karena sesuai dengan data yang tertulis dalam buku tanah dan surat ukur. Jika demikian, maka tolok ukur bagi sertifikat hak milik atas tanah sebagai alat bukti yang kuat tertuju pada kesamaan data yang tersurat dalam sertifikat dengan data yang tertera dalam buku tanah dan surat ukur.

Keberadaan sertifikat hak atas tanah sebagai alat bukti (dalam 
sengketa penguasaan dan/atau pemilikan sebidang tanah), jika dipertautkan dengan Pasal 284 RBg dan Pasal 1866 KUH Perdata, maka sertifikat dimaksud dapat dikategorikan sebagai surat atau alat bukti tertulis dan berbentuk akta otentik. Sedang menurut teori hukum acara (perdata), bahwa yang dimaksud alat bukti tertulis atau surat ialah segala sesuatu yang memuat tanda-tanda bacaan yang dimaksudkan untuk mencurahkan isi hati atau untuk menyampaikan buah pikiran seseorang dan dipergunakan sebagai pembuktian.

Adapun surat sebagai alat bukti tertulis dapat dibagi dua, yakni; surat yang merupakan akta dan surat-surat lain yang bukan akta. Hukum acara perdata telah menetapkan, bahwa yang dimaksud dengan akta adalah surat yang diberi tanda tangan yang memuat peristiwa-peristiwa yang menjadi dasar dari pada suatu hak atau perikatan yang dibuat sejak semula dengan sengaja untuk pembuktian. Sedang eksistensi akta itu sendiri sebagai suatu bentuk alat bukti tulisan, dapat diklasifikasi atas akta otentik dan akta di bawah tangan.

Akta otentik, yaitu akta yang dibuat oleh pejabat yang diberi wewenang untuk itu oleh penguasa menurut ketentuan yang telah ditetapkan, baik dengan maupun tanpa bantuan dari yang berkepentingan yang mencatat apa yang dimintakan untuk dimuat di dalamnya oleh yang berkepentingan, misalnya; sertifikat hak atas tanah. Oleh karena itu, maka akta otentik terutama memuat keterangan seseorang pejabat yang menerangkan apa yang dilakukannya dan dilihat di hadapannya. Lain halnya dengan akta di bawah tangan sebagai suatu akta yang sengaja dibuat untuk pembuktian oleh para pihak tanpa bantuan dari seorang pejabat yang berwenang, contohnya; akte perjanjian jual beli mobil yang dibuat oleh penjual dan pembeli tanpa melibatkan pejabat yang berwenang. Jadi eksistensi dari pada akta di bawah tangan, selalu tidak melibatkan pejabat yang berwenang dalam pembuatannya.

Bertolak dari perbedaan antara akta otentik dengan akta di bawah tangan di atas, maka secara mutatis mutandis setiap sertifikat hak atas tanah sebagai akta otentik senantiasa merupakan bukti sempurna. Artinya sertifikat hak atas tanah merupakan bukti sempurna bagi para pihak dan ahli warisnya serta mereka yang memperoleh hak dari padanya, tentang segala apa yang termuat di dalamnya dan bahkan tentang yang terdapat dalam akta sebagai penuturan belaka sepanjang yang dituturkan itu ada hubungannya langsung dengan pokok akta (Pasal 285 RBg juga Pasal 1870 dan 1871 KUH Perdata).

Eksistensi sertifikat hak atas tanah sebagai akta otentik yang merupakan bukti sempurna, sehingga secara yuridis formal bahwa setiap sertifikat hak atas tanah mempunyai nilai plus, karena setiap sertifikat hak atas tanah dalam bentuk akta otentik dan merupakan bukti sempurna senantiasa mempunyai 2 (dua) kekuatan pembuktian, yakni :

1. Kekuatan pembuktian lahir sertifikat hak atas tanah;

Berdasarkan asas hukum pembuktian yang berbunyi; "acta publica probant sese ipsa", artinya suatu akta yang lahirnya tampak sebagai akta otentik serta memenuhi syarat-syarat yang telah ditentukan, maka akta itu berlaku atau dapat dianggap sebagai akta otentik sampai terbukti 
sebaliknya. Jadi kalau ada orang yang mempersoalkan keberadaannya sebagai akta otentik, maka menurut hukum pembuktian terhadap orang yang bersangkutan dibebankan untuk membuktikan kebenaran dalilnya (Pasal $164 \mathrm{RBg}$ ).

Kekuatan pembuktian lahir terhadap sertifikat hak atas tanah, berlaku pula bagi kepentingan atau keuntungan dan terhadap setiap orang dan tidak terbatas pada para pihak yang tercantum namanya dalam sertifikat hak atas tanah yang bersangkutan. karena itu, nilai plus dari pada sertifikat hak atas tanah sebagai akta otentik terletak pada kekuatan pembuktian lahir.

2. Kekuatan pembuktian formal sertifikat hak atas tanah;

Dikatakan kekuatan pembuktian formil dari suatu sertifikat hak atas tanah sebagai akta otentik, karena secara ex officio membuktikan kebenaran dari pada apa yang dilihat, didengar dan dilakukan oleh pejabat yang menandatangani dan/atau menerbitkan sertifikat hak atas tanah yang bersangkutan. Dalam hal ini, maka terhadap sertifikat hak atas tanah setidak-tidaknya ada tiga hal yang dapat dipastikan kebenarannya, yaitu; kebenaran mengenai keterangan dari pejabat penandatangan, tempat dan tanggal pembuatan sertifikat hak atas tanah, serta tandatangan dari pejabat yang bersangkutan.

Sertifikat hak atas tanah sebagai akta otentik yang dibuat oleh pejabat yang berwenang, menjadi salah satu alasan atau pertimbangan untuk dapat menyatakan bahwa sertifikat hak atas tanah itu adalah salah satu bentuk dari akta pejabat (acta ambtelijk). Kemudian dalam kedudukannya sebagai akta pejabat, berarti segala apa yang tersurat di dalam sertifikat hak atas tanah dipandang sebagai keterangan atau pernyataan dari pejabat yang bersangkutan, dan keterangan dimaksud sudah pasti adanya bagi siapapun juga.

\section{PENUTUP}

Setiap bidang tanah yang dikuasai dan/atau dimiliki sedapat mungkin diamankan dari kemungkinan terjadinya persengketaan dengan seseorang lain, dan salah satu cara mengamankan setiap bidang tanah tersebut harus didaftarkan pada pejabat yang berwenang dan sesuai ketentuan hukum yang berlaku guna mendapatkan perlindungan dan jaminan kepastian hukum. Setiap bidang tanah yang didaftarkan sesuai tata cara, syarat-syarat dan prosedur pendaftaran tanah, out putnya berupa sertifikat hak atas tanah mempunyai nilai plus sebagai bukti sempurna, karena itu setiap sertifikat hak atas tanah dapat dijadikan sebagai alat bukti yang kuat. Adanya nilai plus yang melekat pada setiap sertifikat hak atas tanah sebagai akta otentik, karena terhadapnya memiliki kekuatan pembuktian lahir artinya penyangkalan terhadapnya harus dibuktikan oleh orang yang menyangkalinya, juga memiliki kekuatan pembuktian formil karena segala keterangan yang tersurat di dalamnya dipandang sebaagai keterangan dari pejabat yang menerbitkan dan penerbitannya sesuai dengan ketentuan hukum yang berlaku sehingga sangat sulit untuk dibatalkan dan/atau dinyatakan tidak berlaku. 


\section{DAFTAR PUSTAKA}

Abdurrahman, 1980. Beberapa Aspek Tentang Hukum Agraria; Seri Hukum Agraria V. Bandung, Alumni.

Bachtiar Effendie, 2003. Pendaftaran Tanah Di Indonesia Dan Peraturanperaturan Pelaksanaannya. Alumni, Bandung.

Boedi Harsono, 1961. Undang-undang Pokok Agraria; Sejarah Penyusunan, Isi dan Pelaksanaannya. Jakarta, Djambatan.

Yamin Lubis, Mhd, Dkk., 2010. Hukum Pendaftaran Tanah. Bandung, Mandar Maju.

Parlindungan, A.P., 1990. Pendaftaran Tanah di Indonesia. Bandung, Mandar Maju.

Soehadi, R., Ttp. Penyelesaian Sengketa Tanah Sesudah Berlakunya Undangundang Pokok Agraria. Surabaya, Usaha Nasional.

Sudikno Mertokusumo, 1992. Hukum Acara Perdata Indonesia. Yogyakarta, Liberty.

Wantjik Saleh, K., 1985. Hak Anda Atas Tanah. Jakarta, Ghalia Indonesia.

Yayasan Penyelenggara Penterjemah/Pentafsir Al Qur'an, 1971. Al Qur'an dan Terjemahnya. Khadim al Haramain asy Syarifain. 